\title{
Geostatistics applied to swine facilities equipped with evaporative cooling system
}

\author{
Paulo G. de Abreu ${ }^{1}$, Osmar A. Dalla Costa ${ }^{1}$, Vivian Feddern ${ }^{1}$, \\ Nelson Morés ${ }^{1}$, Arlei Coldebella ${ }^{1} \&$ Clóvis M. C. Ramos ${ }^{2}$ \\ ${ }^{1}$ Embrapa Suínos e Aves. Concórdia, SC. E-mail: paulo.g.abreu@embrapa.br (Corresponding author); osmar.dallacosta@embrapa.br; vivian.feddern@embrapa.br; \\ nelson.mores@embrapa.br; arlei.coldebella@embrapa.br \\ ${ }^{2}$ Universidade Federal do Vale do São Francisco/Colegiado de Pós Graduação em Engenharia Agrícola. Juazeiro, BA. E-mail: clovis.ramos@univasf.edu.br
}

\section{Key words:}

animal welfare spatial analyses environment conditions semivariogram

\begin{abstract}
A B S T R A C T
The purpose of this study was to evaluate the spatial variation of temperature, relative humidity and black globe humidity temperature (BGHT) index in growing-finishing swine facilities, with and without evaporative air cooler. The experiment was conducted in a $60 \times 9 \mathrm{~m}$ facility containing 32 pens of $3.20 \times 4.00 \mathrm{~m}$ each, divided into two sectors. The treatments were without evaporative air cooler (control) and with evaporative air cooler. Temperature and relative humidity data were collected weekly in two periods (morning and afternoon) at 32 different sampling points, encompassing the center of each pen and the outer perimeter of the facility. Animal performance variables were: feed intake, feed conversion, weight out of the nursery, slaughter weight, weight gain and daily weight gain. According to the results, the analyzed variables showed spatial dependence, with lower temperature and higher relative humidity in the evaporative air cooler environment. However, evaporative air cooler system provided better environment thermal conditions inside the facilities, lowering BGHT values, which were lower in the adiabatic cooling sector. Although thermal conditions were better in the air cooler environment, swine performance was not affected.
\end{abstract}

Palavras-chave:

bem estar animal

análise espacial condições do ambiente semivariograma

\section{Geoestatística aplicada às instalações suínas equipadas com sistema de resfriamento evaporativo}

\section{R E S U M O}

Objetivou-se, neste trabalho, avaliar a variação espacial da temperatura, umidade relativa e índice de temperatura de globo negro e umidade (ITGU) em instalações de suínos na fase de crescimento e terminação, com e sem resfriador de ar evaporativo. O experimento foi conduzido em uma edificação de $60 \times 9$ m, contendo 32 baias de 3,20 x 4,00 m cada uma, divididos em dois setores. Os tratamentos foram sem resfriador de ar evaporativo (controle) e com resfriador de ar evaporativo sendo os dados de temperatura e umidade relativa coletados semanalmente em dois períodos (manhã e tarde) em 32 pontos de amostragem diferentes abrangendo o centro de cada baia e o perímetro exterior das instalações. As variáveis de desempenho dos animais foram: consumo de ração, conversão alimentar, peso ao sair da creche, peso ao abate, ganho de peso e ganho de peso diário. Os resultados mostraram que as variáveis analisadas apresentaram dependência espacial com temperatura mais baixa e umidade do ar mais alta no setor com resfriador evaporativo. Desta forma, o resfriamento evaporativo melhorou as condições térmicas ambientais no interior da instalação, reduzindo os valores do ITGU, os quais foram menores no setor de resfriamento adiabático. Embora o conforto térmico do ambiente com resfriamento evaporativo tenha sido melhor, os suínos não responderam a esta melhoria, em termos de desempenho. 


\section{INTRODUCTION}

From the 70s, pig production began to be held in a confinement system aiming to improve the sanitary control, reduce energy loss from the animal and increase productivity (Sampaio et al., 2007). Under heat stress, the production efficiency, reproduction, feed conversion, health and welfare of pigs can be severely affected. Physiological and behavioral responses and thus swine production in tropical conditions can be favored by adopting evaporative cooling, as water evaporation to the atmosphere is usually an effective solution to alleviate heat stress (Haeussermann et al., 2007).

Air temperature and relative humidity $(\mathrm{RH})$ inside facilities influence animal health and performance. By using evaporative cooling system, environment thermal conditions may improve (Ponciano et al., 2013; Liang et al., 2014). Sartor et al. (2003) reported a reduction in the black globe humidity index inside the facility from 83.5 to 82.4 during the critical period of the day (2 p.m.), besides reduction in feed conversion from 3.27 to 2.88 , and increase in weight gain, from 0.97 to $1.02 \mathrm{~kg}$ a day.

Currently, traditional statistical analysis based on means has been replaced by geostatistical analyses, in which semivariograms consider the spatial dependence between observed samples. According to Vieira (2000), when the studied attribute varies from a place to another, geostatistics is a tool that enables the spatial vision of this behavior based on the spatial dependence. The geostatistics concept has been applied in different fields as a tool to study the variability of environment attributes. Also in breeding facilities, it is of great importance in interpreting and understanding results, based on the structure of its natural variability, mainly the interaction between physical attributes of the environment (Wang et al., 2002).

In this context, this research aimed to evaluate the spatial variability of air temperature and relative humidity $(\mathrm{RH})$ in growingfinishing swine facilities with and without air cooler system, besides evaluating swine performance under these conditions.

\section{Material ANd Methods}

The experiment was developed in a farm destined for growing-finishing swine production, at Santo Antônio district, Concórdia, Santa Catarina state, Brazil, during summer period in the Southern hemisphere from November to February.
The facility area was $60 \times 9 \mathrm{~m}$, covering 32 pens measuring $3.20 \times 4.00 \mathrm{~m}$, central corridor of $1 \mathrm{~m}$, ceiling height of $2.5 \mathrm{~m}$, divided into two sectors separated by 50 micra black canvas curtains, containing one treatment each. The facility was opened with natural thermal conditioning and management of yellow polyethylene curtain. At ceiling height, liner was placed with the same material as the curtain. The roof consisted of $6-\mathrm{mm}$ fiber cement and masonry gables. These treatments consisted of: environment without evaporative air cooler (control) and with evaporative air cooler. Sixteen pens housed control animals, submitted to conventional system, an open facility in natural thermal conditions without any mechanical ventilation and cooling system. The remaining sixteen pens were equipped with evaporative air cooler system. In this system, four Joape 777 coolers were used, two at each row of pen, distributed longitudinally at the center of the pen at $1.5 \mathrm{~m}$ height (Figure 1). These coolers had the following characteristics: $18,000 \mathrm{~m}^{3}$ air flow, $74 \mathrm{~dB}$ noise level, $430 \mathrm{~W}$ consumption and $1.0 \times 1.07 \times 0.37$ $\mathrm{m}$ dimensions; and were activated by automatic thermostat $( \pm$ $0.1^{\circ} \mathrm{C}$ accuracy), adjusted to turn on and off when temperature reached $27.0^{\circ} \mathrm{C}$ and $26.9^{\circ} \mathrm{C}$, respectively.

Thirty-two sampling points were examined in the experiment, according to Figure 1; half of sampling was performed around the facility at the highest point of each pen, and the other half measurements were taken inside the facility at the center of each pen for both systems. At each sampling point, temperature and $\mathrm{RH}$ were measured using a multifunction device $\left(\mathrm{TESTO}^{\circledR}\right)$, weekly at 9 a.m. and 2 p.m. throughout the 16 experimental weeks, totalizing 1,024 samples each treatment.

A total of 352 animals, half male and half female, from industrial Agroceres PIC crossbreeding, were utilized. Each pen housed 11 animals aged 58 days and with $23 \mathrm{~kg}$ of mean weight. Animal performance was evaluated through the following variables: feed intake, feed conversion, weight out of the nursery, slaughter weight, weight gain, and daily weight gain in growing-finishing periods (112 days). These variables were evaluated through analyses of variance using the GLM procedure of SAS, taking into account the effects of sex, block (initial weight and pen location) within the sex, treatment and interaction between treatment and sex.

The black globe humidity temperature (BGHT) index is the most precise indicative of thermal comfort in animal production according to Buffington et al. (1981), who proposed

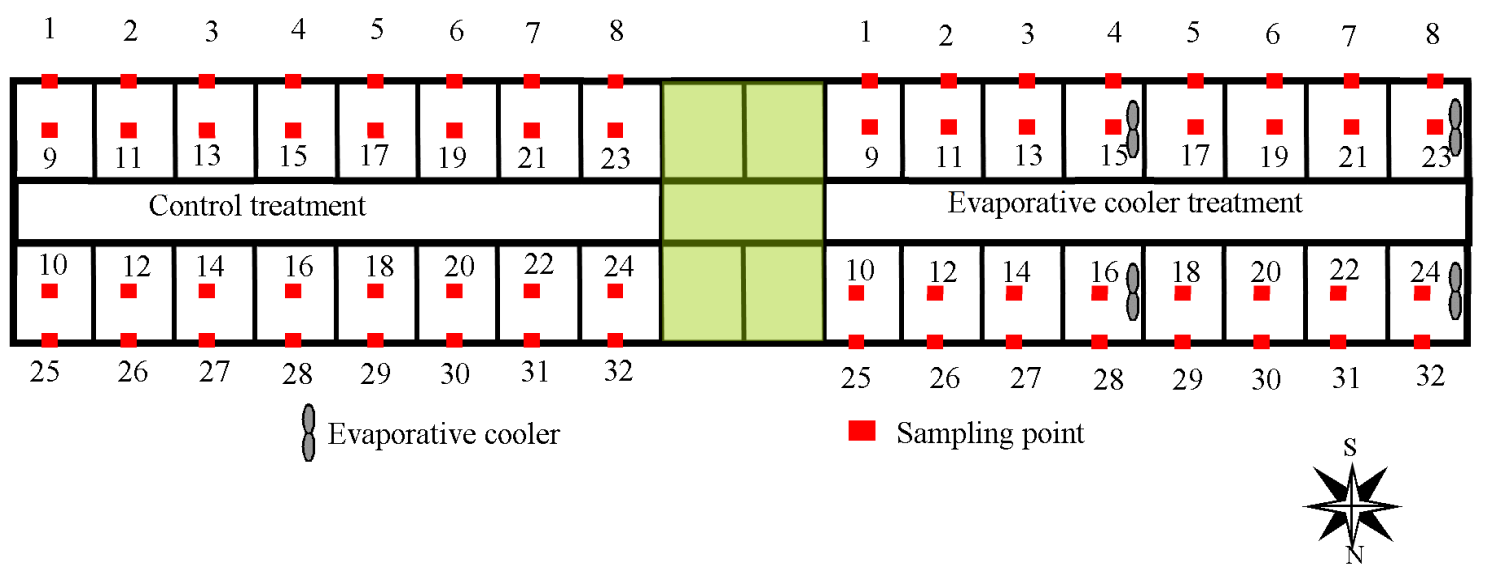

Figure 1. Distribution of treatments and sampling points for temperature and $\mathrm{RH}$ at swine growing-finishing phases 
BGHT calculation through data collected at each point, following Eq. 1:

$$
\mathrm{BGHT}=\mathrm{Tbg}+0.36 \mathrm{Tdp}-330.08
$$

where:

Tbg - black globe temperature, K; and,

Tdp - dew point temperature, $\mathrm{K}$.

Tbg for covered environment was estimated from Eq. 2 (Abreu et al., 2011):

$$
\mathrm{Tbg}=0.456+1.0335 \mathrm{Tdb}
$$

where:

Tbg - black globe temperature, ${ }^{\circ} \mathrm{C}$; and,

$\mathrm{Tdb}$ - dry bulb temperature, ${ }^{\circ} \mathrm{C}$.

According to temperature and $\mathrm{RH}$ values in the morning and afternoon at each point, the spatial analysis of data was carried out using $\mathrm{GS}^{+}$software. Data were submitted to geostatistical analysis, where the model was chosen based on the smallest residual sum of squares (RSS), identifying parameters as the nugget effect $(\mathrm{Co})$, sill $\left(\mathrm{Co}+\mathrm{C}_{1}\right)$ and range (Ao). In order to verify the existence of spatial dependence, the spatial dependence index (SDI), which is the ratio representing the percentage of data variability explained by spatial dependence, was adapted from Kitamura et al. (2007) according to Eq. 3. It may be classified as weak (SDI $\leq 25 \%)$, moderate $(25 \%<$ SDI $<75 \%)$ and strong $(\mathrm{SDI} \geq 75 \%)$.

$$
\mathrm{SDI}=\left(\frac{\mathrm{C}_{1}}{\mathrm{Co}+\mathrm{C}_{1}}\right) \times 100
$$

where:

SDI - evaluator index of the spatial dependence ratio; and,

$\mathrm{C}_{1}$ - spatial variance; and

$\mathrm{Co}+\mathrm{C}_{1}$ - total variance (sill) for the semivariogram.

\section{Results AND Discussion}

In total 1,024 recordings were obtained during the experimental period (Table 1). The temperature varied from 24.0 to $25.9^{\circ} \mathrm{C}$ in the morning and from 27.3 to $29.3^{\circ} \mathrm{C}$ in the afternoon. The RH ranged from 62.04 to $68.82 \%$ in the morning and from 52.55 to $58.77 \%$ in the afternoon. BGHT index in the morning varied between 72.91 and 74.97 , and in the afternoon, between 76.39 and 78.64. Throughout the experimental time frame, the outside conditions were: $34.6{ }^{\circ} \mathrm{C}$ the maximum temperature average and $38 \%$ the minimum $\mathrm{RH}$ average.

In order to allow scrutiny of variables, histograms were built to visualize the variable behavior in relation to data concentration trend (symmetric or asymmetric). This trend especially for the non-spatial analysis of data can drive different analytical procedures. In this way, data distributions regarding temperature, $\mathrm{RH}$ and BGHT index in the morning and afternoon have not obeyed a normal distribution (Figure 2).

Semivariograms are illustrated in Figure 3, while the parameters used in the analysis are shown in Table 2. There was a strong spatial dependence of data in both studied periods, with the best fit spherical model represented by the high value of the coefficient of determination $\left(\mathrm{R}^{2}\right)$ and low value of RSS.

The spherical model is one of the most commonly used models in geostatistical analysis according to results presented by Campos et al. (2009) and Liu et al. (2009). Ramos et al. (2009) also identified a strong time dependence of temperature data along the day for 365 days, being such dependence significant

A

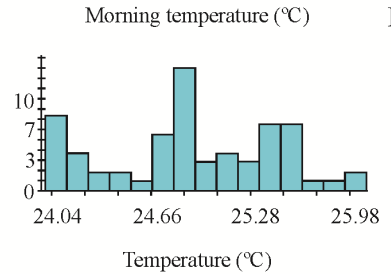

C.
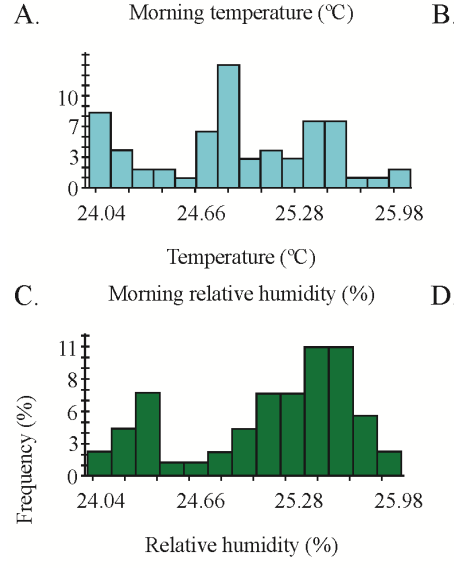

E.

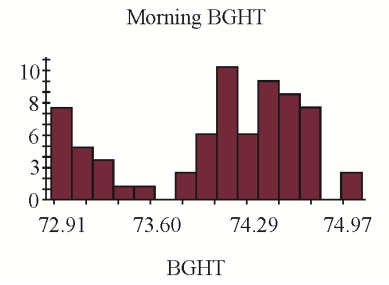

F.
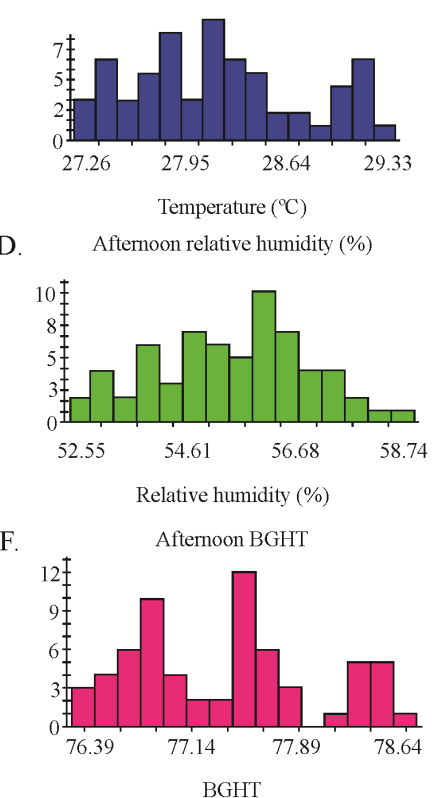

Figure 2. Frequency distribution of temperature (A, B), relative humidity $(C, D)$ and black globe humidity temperature -

\begin{tabular}{|c|c|c|c|c|c|c|}
\hline Parameters & $\begin{array}{c}\text { Temperature } \\
\text { morning }\end{array}$ & $\begin{array}{l}\text { Temperature } \\
\text { afternoon }\end{array}$ & $\begin{array}{l}\text { Humidity } \\
\text { morning }\end{array}$ & $\begin{array}{l}\text { Humidity } \\
\text { afternoon }\end{array}$ & $\begin{array}{c}\text { BGHT } \\
\text { Morning }\end{array}$ & $\begin{array}{c}\text { BGHT } \\
\text { afternoon }\end{array}$ \\
\hline Number of sampling points & 64 & 64 & 64 & 64 & 64 & 64 \\
\hline Number of observations & 1,024 & 1,024 & 1,024 & 1,024 & 1,024 & 1,024 \\
\hline Number of missing data & 0 & 0 & 0 & 0 & 0 & 0 \\
\hline Minimum value, ${ }^{\circ} \mathrm{C}$ & 24.0 & 27.3 & 62.0 & 52.5 & 72.9 & 76.4 \\
\hline Maximum value, ${ }^{\circ} \mathrm{C}$ & 25.9 & 29.3 & 68.4 & 58.7 & 74.9 & 78.6 \\
\hline Amplitude, ${ }^{\circ} \mathrm{C}$ & 1.9 & 2.0 & 6.4 & 6.2 & 2.0 & 2.2 \\
\hline Mean, ${ }^{\circ} \mathrm{C}$ & 24.9 & 28.2 & 65.8 & 55.5 & 74.0 & 77.4 \\
\hline Standard deviation & 0.52 & 0.58 & 1.78 & 1.48 & 0.60 & 0.63 \\
\hline Coefficient of Variation & 0.28 & 0.34 & 3.18 & 2.21 & 0.81 & 0.81 \\
\hline Coefficient of Asymmetry & $-0.11(0.3)$ & $0.36(0.3)$ & $-0.73(0.3)$ & $-0.14(0.3)$ & $-0.65(0.3)$ & $0.35(0.3)$ \\
\hline Coefficient of Kurtosis & $-0.98(0.59)$ & $-0.86(0.59)$ & $-0.73(0.59)$ & $-0.74(0.59)$ & $-0.83(0.59)$ & $-0.92(0.59)$ \\
\hline
\end{tabular}
$\mathrm{BGHT}(\mathrm{E}, \mathrm{F})$ data in the morning and afternoon periods

Table 1. Exploratory analysis on temperature and average humidity data in the morning and afternoon periods 

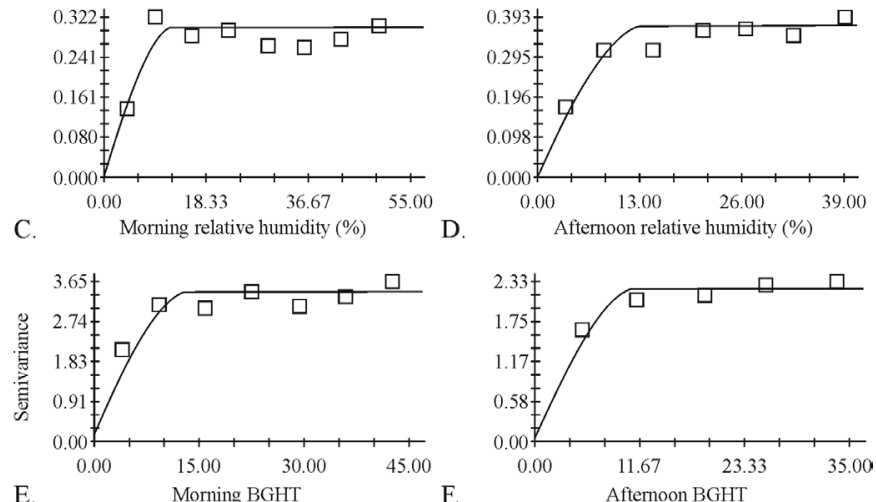
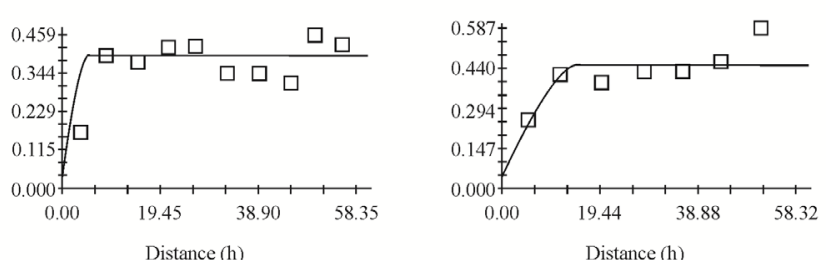

The curve corresponds to the spherical model fitted to the distribution of dots

Figure 3. Semivariograms of temperature $(A, B)$, relative humidity $(\mathrm{C}, \mathrm{D})$ and $\mathrm{BGHT}(\mathrm{E}, \mathrm{F})$ in the morning and afternoon periods

within $12 \mathrm{~h}$ interval when temperature change occurred in a significant way according to geostatistical analysis.

The semivariogram fit enabled to estimate values for nonsampled locations regarding temperature, $\mathrm{RH}$ and BGHT index by ordinary kriging, which estimates spatial distributed variables through moving average values. A stratification of temperature through the facility in both treatments was observed (Figure 4A).

As already expected, higher values of temperature in the afternoon were accompanied by lower RH, unlike observed in the morning (Figures $4 \mathrm{~A}$ and $\mathrm{B}$ ). In an environment with evaporative cooler, air temperature was lower and more homogeneous in both day periods than in the environment without cooler. In the afternoon the difference between systems was only $2{ }^{\circ} \mathrm{C}$.

Lower temperature and higher $\mathrm{RH}$ values in the environment with coolers were observed close to the place where coolers were set. These were effective in maintaining the environment temperature pre-set in the thermostat. However, this was not homogeneous throughout the facility. Air RH was greater in the environment with cooler either in the morning or afternoon (Figure 4B).

As the experiment was conducted in the Southern hemisphere, the northern side of the facility presented higher values of temperature and lower values of $\mathrm{RH}$ in comparison to the southern side at both periods. This condition was due to solar output along the day on the facility oriented in the east-west direction.

According to Haeussermann et al. (2007), evaporative coolers are efficient to relieve heat stress in swine. However, the effect of increasing RH by evaporative cooling in closed facilities is still controversial. These same authors concluded that the evaporative fraction reached $100 \%$ during steady state, and $63 \%$ under warm and dry environment conditions $\left(28^{\circ} \mathrm{C}\right.$ and $53 \% \mathrm{RH})$. Under moderate conditions $\left(21^{\circ} \mathrm{C}\right.$ and $\left.69 \%\right)$ the evaporative fraction reached $89 \%$ and under cold conditions $\left(13{ }^{\circ} \mathrm{C}\right.$ and $\left.83 \%\right)$, the evaporative fraction reached $65 \%$.

As shown in Figure 4B, the maximum RH value was 58\% in the environment with cooler in the afternoon, which is the

Table 2. Parameters of the theoretical semivariogram from temperature and humidity in the morning and afternoon periods via ordinary kriging

\begin{tabular}{lcccccc}
\hline \multicolumn{1}{c}{ Parameters } & $\begin{array}{c}\text { Temperature } \\
\text { morning }\end{array}$ & $\begin{array}{c}\text { Temperature } \\
\text { afternoon }\end{array}$ & $\begin{array}{c}\text { Humidity } \\
\text { morning }\end{array}$ & $\begin{array}{c}\text { Humidity } \\
\text { afternoon }\end{array}$ & $\begin{array}{c}\text { BGHT } \\
\text { morning }\end{array}$ & $\begin{array}{c}\text { BGHT } \\
\text { afternoon }\end{array}$ \\
Fitted Model & Spherical & Spherical & Spherical & Spherical & Spherical & Spherical \\
Co & $1.00 \mathrm{E}-04$ & $2.00 \mathrm{E}-03$ & $1.16 \mathrm{E}+00$ & $2.10 \mathrm{E}-02$ & $2.43 \mathrm{E}-02$ & $3.11 \mathrm{E}-02$ \\
$\mathrm{C}_{0}+\mathrm{C}_{1}$ & $3.01 \mathrm{E}-01$ & $3.71 \mathrm{E}-01$ & $3.43 \mathrm{E}+00$ & $2.23 \mathrm{E}+00$ & $3.98 \mathrm{E}-01$ & $4.53 \mathrm{E}-01$ \\
$\mathrm{~A}_{0}$ & 1270.00 & 13.80 & 13.80 & 1156.00 & 5.48 & 16.17 \\
$\mathrm{R}^{2}$ & 0.75 & 0.88 & 0.82 & 0.84 & 0.71 & 0.60 \\
RSS & $6.70 \mathrm{E}-03$ & $5.56 \mathrm{E}-03$ & $6.61 \mathrm{E}-01$ & $9.69 \mathrm{E}-02$ & $5.11 \mathrm{E}-02$ & $2.47 \mathrm{E}-02$ \\
SDI (\%) & 100 & 99.5 & 95.2 & 99.1 & 93.9 & 93.1 \\
SDI classification & strong & strong & strong & strong & strong & strong \\
\hline
\end{tabular}

Co - Nugget effect; $C_{0}+C_{1}$ - Total variance (sill); Ao - Range; $R^{2}$ - Coefficient of determination; RSS - Residual sum of squares; SDI - Spatial dependence index

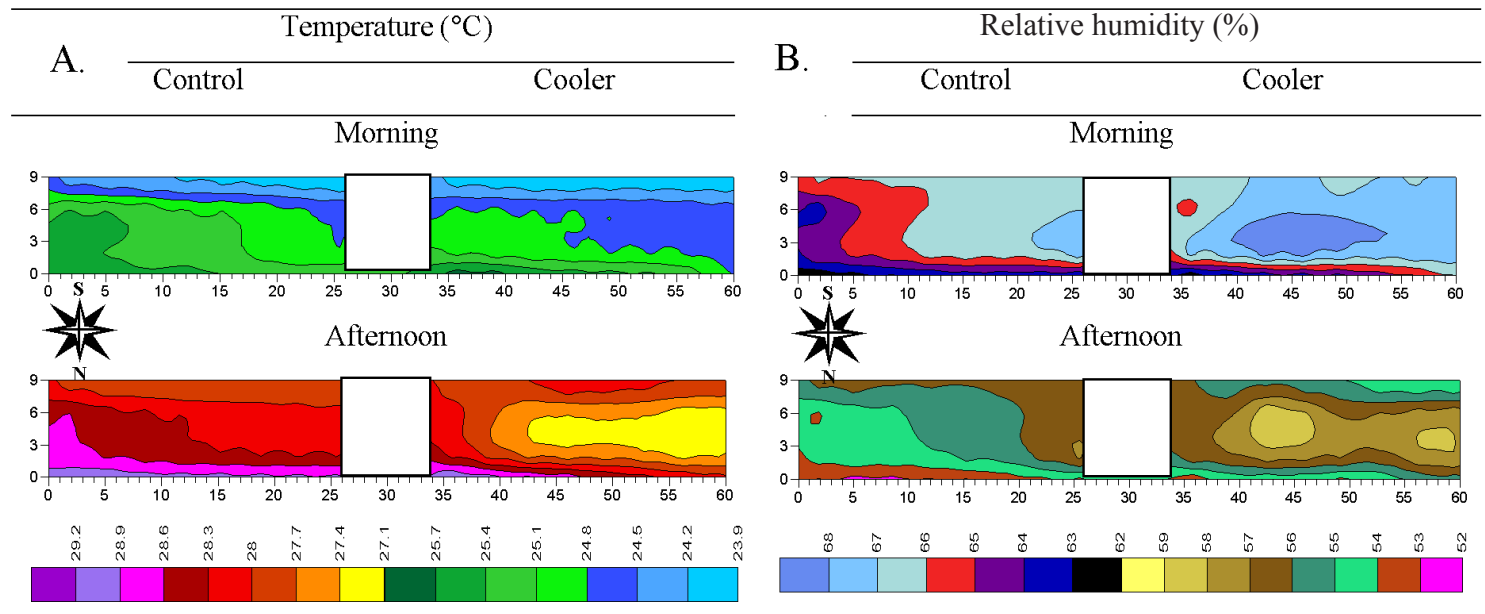

Figure 4. Isoline temperature $\left({ }^{\circ} \mathrm{C}\right)$ and relative humidity $(\%)$ maps in the morning and afternoon periods 
most stressful period for animals, evidencing that the air still had evaporative capacity.

Sartor et al. (2003) reported that evaporative cooling system improved thermal conditions inside the facilities for finishing swine, by reducing BGHT index, as well as providing better feed conversion and greater weight gain of animals.

BGHT index values characterized as thermoneutral environment by Orlando et al. (2006) were close to 69.1 and 68.7 for swine kept under thermal comfort. As observed in Figure 5, these values were not achieved in the environment with and without evaporative cooler, showing that, despite the temperature decreases and $\mathrm{RH}$ increases using coolers, they were not effective in promoting animal thermal comfort.

No significant effect $(p>0.05)$ was observed for evaporative cooling system regarding feed intake, feed conversion, weight gain out of the nursery, slaughter weight, weight gain and daily weight gain (Table 3 ).
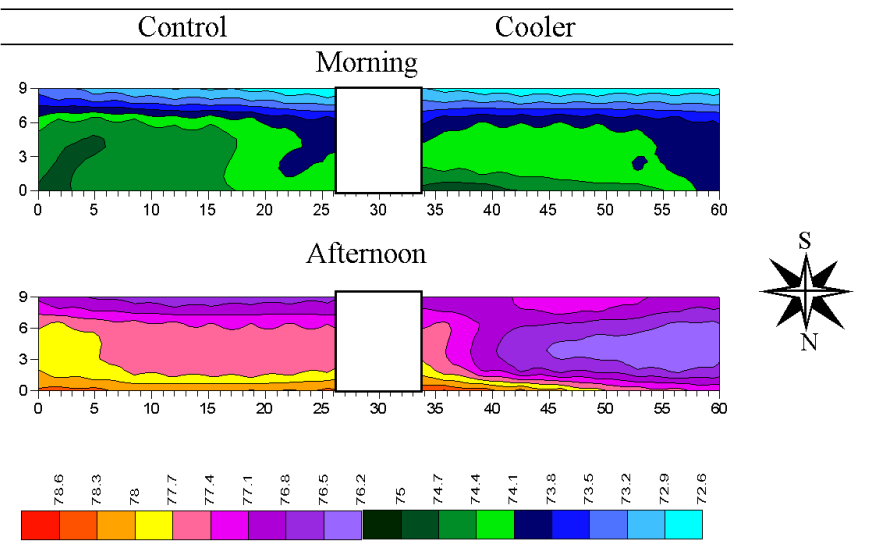

Figure 5. Isoline maps for black globe humidity temperature $(\mathrm{BGHT})$ in the morning and afternoon periods

Table 3. Means and standard errors of performance variables according to sex and treatment (cooling system)

\begin{tabular}{|c|c|c|c|c|}
\hline \multirow{2}{*}{ Sex } & \multicolumn{2}{|c|}{ Treatments } & \multirow{2}{*}{$\begin{array}{c}\text { Overall } \\
\text { mean }\end{array}$} & \multirow{2}{*}{$\operatorname{Pr}>\mathrm{F}$} \\
\hline & Cooler & Control & & \\
\hline \multicolumn{5}{|c|}{ Feed intake $(\mathrm{kg})$} \\
\hline Male & $195 \pm 3.0$ & $200 \pm 5.0$ & $197 \pm 3.0$ & 0.4849 \\
\hline Female & $190 \pm 6.0$ & $195 \pm 7.0$ & $193 \pm 5.0$ & 0.5214 \\
\hline Mean & $193 \pm 3.0$ & $197 \pm 4.0$ & $195 \pm 3.0$ & \\
\hline \multicolumn{5}{|c|}{ Feed conversion } \\
\hline Male & $2.40 \pm 0.04$ & $2.44 \pm 0.06$ & $2.42 \pm 0.04$ & 0.6516 \\
\hline Female & $2.30 \pm 0.06$ & $2.39 \pm 0.09$ & $2.34 \pm 0.05$ & 0.2935 \\
\hline Mean & $2.35 \pm 0.04$ & $2.41 \pm 0.05$ & $2.34 \pm 0.05$ & \\
\hline \multicolumn{5}{|c|}{ Weight out of the nursery $(\mathrm{kg})$} \\
\hline Male & $23.60 \pm 0.51$ & $23.60 \pm 0.51$ & $23.60 \pm 0.35$ & 0.7712 \\
\hline Female & $23.84 \pm 0.62$ & $23.86 \pm 0.62$ & $23.83 \pm 0.42$ & 0.1317 \\
\hline Mean & $23.72 \pm 0.39$ & $23.73 \pm 0.39$ & $23.72 \pm 0.27$ & \\
\hline \multicolumn{5}{|c|}{ Slaughter weight $(\mathrm{kg})$} \\
\hline Male & $106 \pm 1.0$ & $108 \pm 1.0$ & $107 \pm 1.0$ & 0.3984 \\
\hline Female & $108 \pm 2.0$ & $108 \pm 2.0$ & $108 \pm 1.0$ & 0.6902 \\
\hline Mean & $107 \pm 1.0$ & $108 \pm 1.0$ & $107 \pm 1.0$ & \\
\hline \multicolumn{5}{|c|}{ Weight gain $(\mathrm{kg})$} \\
\hline Male & $82.75 \pm 1.02$ & $84.17 \pm 1.16$ & $83.46 \pm 0.77$ & 0.3966 \\
\hline Female & $84.41 \pm 1.49$ & $83.73 \pm 1.48$ & $84.07 \pm 1.02$ & 0.6828 \\
\hline Mean & $83.58 \pm 0.90$ & $83.95 \pm 0.91$ & $83.77 \pm 0.63$ & \\
\hline \multicolumn{5}{|c|}{ Daily weight gain $\left(\mathrm{g} \mathrm{d}^{-1}\right)$} \\
\hline Male & $739 \pm 9.0$ & $752 \pm 10.0$ & $745 \pm 7.0$ & 0.3966 \\
\hline Female & $754 \pm 13.0$ & $748 \pm 13.0$ & $751 \pm 9.0$ & 0.6828 \\
\hline Mean & $746 \pm 8.0$ & $750 \pm 8.0$ & $748 \pm 6.0$ & \\
\hline
\end{tabular}

Evaporative cooling system improved physiological, behavioral and productive responses from growing swine (Huynh et al., 2006), environmental thermal condition (Sartor et al., 2003) and provided an increase in weaning piglet weight (Justino et al., 2015). Otherwise, Collin et al. (2001) reported that weight gain and voluntary feed intake of swine were reduced by up to 37 and $30 \%$ respectively at $33^{\circ} \mathrm{C}$ when compared to $23^{\circ} \mathrm{C}$.

Nevertheless, little is known about the benefits of evaporative cooling system at finishing phase, as heat stress relief, as well as management procedures required by this system, once the efficiency of the evaporative cooling is directly influenced by local microclimatic conditions, and by animal physiological and behavioral responses.

\section{Conclusions}

1. Higher RH values and lower temperatures were found with evaporative cooler, providing better environment conditions for pigs compared with the environment without cooler.

2. The environment with evaporative cooler showed that temperature and $\mathrm{RH}$ conditions are prone to increase the equipment efficiency.

3. The spatialization of temperature, $\mathrm{RH}$ and BGHT index provided more detailed information on the operation of the evaporative cooler, although this equipment does not provide thermal comfort for swine.

4. Even modifying thermal conditions using evaporative air cooler, it was not enough to enhance pig performance; also, daily weight gain did not show significant difference ( $\mathrm{p}$ $>0.05$ ) between sex.

5. By psychometric air conditions presented within the facility, it is urged to adopt more air coolers or replace them by other evaporative cooling system, so that animals respond to environment change.

\section{ACKNOWLeDgements}

To Joape company, for providing evaporative coolers. To CNPq/MAPA Process \# 577860/2008-9, for the financial support.

\section{Literature Cited}

Abreu, P. G.; Abreu, V. M. N.; Franciscon, L.; Coldebella, A.; Amaral, A. G. Estimating black globe temperature from the dry bulb temperature. Engineering in Agriculture, v.19, p.557-563, 2011.

Buffington, D. E.; Colazzo-Arocho, A.; Canton, G. H.; Pitt, D.; Thatcher, W. W.; Collier, R. J. Black globe-humidity index (BGHI) as comfort equation for dairy cows. Transactions of the ASAE, v.24, p.711-714, 1981. http://dx.doi.org/10.13031/2013.34325

Campos, M. C. C.; Marques Júnior, J.; Pereira, G. T.; Souza, Z. M. de; Montanari, R. Agricultural planning and implementation of cultivation systems for sugarcane using geostatistics techniques. Revista Brasileira de Engenharia Agrícola e Ambiental, v.13, p.297-304, 2009.

Collin, A.; Milgen, J. van; Dubois, S.; Noblet, J. Effect of high temperature on feeding behaviour and heat production in grouphoused young pigs. The British Journal of Nutrition, v.86, p.63-70, 2001. http://dx.doi.org/10.1079/BJN2001356 
Haeussermann, A.; Hartung, E.; Jungbluth, T.; Vranken, E.; Aerts, J. M.; Berckmans, D. Cooling effects and evaporation characteristics of fogging systems in an experimental piggery. Biosystems Engineering, v.97, p.395-405, 2007. http://dx.doi.org/10.1016/j. biosystemseng.2007.03.019

Huynh, T. T. T.; Aarnink, A. J. A.; Truong, C. T.; Kemp, B.; Verstegen, M. W. A. Effects of tropical climate and water cooling methods on growing pigs' responses. Livestock Science, v.104, p.278-291, 2006. http://dx.doi.org/10.1016/j.livsci.2006.04.029

Justino, E.; Nääs, I. A.; Carvalho, T. M. R.; Salgado, D. A. Effect of evaporative cooling and electrolyte balance on lactating sows in tropical summer conditions. Arquivo Brasileiro de Medicina Veterinária e Zootecnia, v.67, p.455-464, 2015. http://dx.doi. org/10.1590/1678-6478

Kitamura, A. E.; Carvalho, M. P.; Lima, C. G. R. Relationship between the spatial variability of particle-size fractions of soil and common bean yield under no-tillage. Revista Brasileira de Ciência do Solo, v.31, p.361-369, 2007. http://dx.doi.org/10.1590/S010006832007000200018

Liang, Y; Tabler, G. T.; Costello, T. A.; Berry, I. L.; Watkins, S. E.; Thaxton, Y. V. Cooling broiler chickens by surface wetting: indoor thermal environment, water usage, and bird performance. Applied Engineering in Agriculture, v.30, p.249-258, 2014.

Liu, X.; Zhang, W.; Zhang, M.; Darren, L. F.; Wang, F. Spatio-temporal variations of soil nutrients influenced by an altered land tenure system in China. Geoderma, v.152, p.23-34, 2009. http://dx.doi. org/10.1016/j.geoderma.2009.05.022
Orlando, U. A. D.; Oliveira, R. F. M.; Donzele, J. L.; Ferreira, R. A.; Vaz, R. G. M. V. Dietary crude protein levels with amino acid supplementation for gilts from 60 to $100 \mathrm{~kg}$ on thermoneutral environment. Brazilian Journal of Animal Science, v.35, p.478484, 2006. http://dx.doi.org/10.1590/S1516-35982006000200020

Ponciano, P. F.; Yanagi Júnior, T.; Ferraz, G. A. E. S.; Scalon, J. D.; Schiassi, L. Spatial variability of air dry bulb temperature and black globe humidity index in a broiler house during the heating phase. Engenharia Agrícola, v.33, p.433-444, 2013. http://dx.doi. org/10.1590/S0100-69162013000300001

Ramos, C. M. C.; Nardini, R. C.; Zimback, C. R. L.; Seraphin, S. Análise temporal da variação da temperatura utilizando-se a geoestatística. In: Simpósio Brasileiro de Sensoriamento Remoto, 14, 2009, Natal. Anais... Natal: INPE, 2009. p.347-353.

Sampaio, C. A. P.; Nääs, I. A.; Salgado, D. D.; Queiroz, M. Evaluation of the noise level in swine housing. Revista Brasileira de Engenharia Agrícola e Ambiental, v.11, p.436-440, 2007. http://dx.doi. org/10.1590/S1415-43662007000400014

Sartor, V.; Baeta, F. C.; Tinoco, I. de F. F.; Luz, M. L. Perfomance of an evaporative cooling system of a finishing phase swine barn. Scientia Agricola, v.60, p.13-17, 2003. http://dx.doi.org/10.1590/ S0103-90162003000100003

Vieira, S. R. Geostatistics in soil variability studies. In: Novais, R. F; Álvarez V., H.; Schaefer, G. R. (ed.). Topics in soil science. Viçosa: Brazilian Society of Soil Science, v.1, 2000. p.1-54.

Wang, X.; Zhang, Y.; Riskowski, G. L.; Ellis, M. Measurement and analysis of dust spatial distribution in a mechanically ventilated pig building. Biosystems Engineering, v.81, p.225-236, 2002. http://dx.doi.org/10.1006/bioe.2001.0014 